\title{
Nuclear nations should take the lead in disarming
}

\section{A willingness to use 'overwhelming force' encourages other states to arm themselves.}

Sir - We are glad to see that Nature is taking a strong line about the growing dangers of nuclear proliferation ("We have the technology" Nature 432, 432-437; 2004). When the Berlin Wall came down it was easy to become complacent: most people believed that the dangers of nuclear weapons had receded. That has proved overoptimistic. Nature is right to point out that the increasing number of states possessing, or on the point of possessing, nuclear weapons gives grave cause for alarm. We strongly support the view that scientists have a special responsibility to restrain these trends.

In his Commentary in the same issue, C. P. Robinson ("Revisiting the Baruch Plan” Nature 432, 441-442; 2004) takes the view that the nuclear non-proliferation treaty (NPT) is not the right tool with which to tackle this problem because of its "basic structural problems", which he says the world is not yet ready to address. He proposes, instead, a gradual strengthening of regional alliances. This should be given careful consideration. But let us not forget that the original nuclear powers, when they signed the NPT, made an "unequivocal undertaking to accomplish the total elimination of their nuclear arsenal". We believe that the right approach is for the nuclear powers to abandon those policies that are incompatible with the letter and the spirit of the NPT.

For example, Robinson's claim that "The United States has been leading an international effort to reduce existing nuclear stockpiles, including its own" is not supported by talk of new 'bunker-busting' nuclear weapons. Congress has denied funds for 2005, but the administration has renewed its request for 2006. Furthermore, the administration has affirmed — in its "National Strategy to Combat Weapons of Mass Destruction", December 2002 — its willingness to use pre-emptive measures against WMD-armed adversaries (a course contrary to Article 2(4) of the UN Charter) and to respond to an attack with overwhelming force, including use of WMD.

We believe that the failure of the official five nuclear states to abide by their NPT obligations encourages proliferation, by providing an excuse for other nations to acquire nuclear weapons. The United Kingdom, for example, should phase out its 'independent' nuclear weapons, such as Trident submarine-based systems.

Robinson claims that the United Nations "is not now an organization that can satisfactorily demonstrate security leadership". The United Nations must be brought up to date, but that can only happen with US support and US willingness to take a less self-centred and more global view than it is doing at present.

Robert A. Hinde

British Pugwash Group, 63a Great Russell Street, London WC1B 3BJ, UK

\section{Military alliances offer no nuclear security}

Sir - We welcome your Editorial (“Conscience call” Nature 432, 421; 2004), calling for active engagement by scientists in addressing the problems of nuclearweapons proliferation. But the 'solution' proposed by C. P. Robinson of the Sandia National Laboratory in his Commentary article, "Revisiting the Baruch Plan" (Nature 432, 441-442; 2004), is an unlikely route to safety. He suggests more military alliances, each with a nuclear umbrella state providing 'security', forming a worldwide network of nuclear deterrence.

Would it not be more effective, and safer, to build alliances of nuclear-weaponsfree countries? There are already several large and legally recognized nuclearweapons-free zones (NWFZ). These include the areas covered by the Treaty of Tlatelolco in Latin America, of Rarotonga in the Pacific, of Bangkok in Southeast Asia and (yet to enter into force) of Pelindaba in Africa. Some states, including Mongolia and New Zealand, have individually declared themselves nuclear-weapons-free. Proposals have also been made for NWFZ in central Europe and the Middle East.

These treaties or decisions bind their adherents to non-nuclear policies. Some are recognized by the nuclear-weapons states, which agree not to use nuclear weapons against countries in the NWFZ.

If, as Robinson suggests, most or all states were linked to nuclear military alliances, this would render them all liable to nuclear attack. NWFZs will tend to reduce the proliferation of nuclear weapons, and simultaneously make such countries safer by diminishing the overall likelihood of nuclear conflict.

In our view, the way forward is to treat nuclear weapons like other weapons of mass destruction (WMD), which have all involved scientists in their development. Chemical and biological weapons are forbidden by treaty. There exists a model Nuclear Weapons Convention, introduced into the United Nations in 1997 by Costa Rica. Its entry into force would end the hypocrisy of the nuclear-weapons states lecturing other countries for their nuclear ambitions. All WMD would be forbidden; there would be no need for WMDdependent alliances; the entire globe would be a nuclear-weapons-free zone.

Dominique Lalanne ${ }^{\star}$, Peter Nicholls $\dagger$, Joseph Rotblat

*Accélérateur Linéaire, 91898 Orsay, France $\dagger$ University of Essex, Colchester, Essex CO4 3SQ, UK $\$ 8$ Asmara Road, London NW2 3ST, UK

\section{Would you accept advice from a believer in Santa?}

Sir - I was horrified to read the recent Editorial "Where theology matters" (Nature 432, 657; 2004) in the world's foremost science journal. Not only did the Editorial appear to support the position that science and religion deal with different aspects of reality (which they do not: for example, either Jesus rose from the dead or he didn't - clearly a scientific question), but it also implied that religion has some privileged position in ethical debates.

This view is reflected in many public discussions of moral issues, where the obligatory priest or rabbi is wheeled out to comment on some topic, in spite of their utter lack of any qualification other than a belief in a paranormal entity that created the Universe and all it contains. Would you be prepared to accept fundamental advice from someone who insisted that Father Christmas was real?

The suggestion that religion has an intrinsic and predestined role in any ethical debate is indefensible, as a simple read of the ethics promulgated by the Old Testament (for example) will make abundantly clear. In most parts of the world, and certainly in the Western world, we no longer stone adulterers to death, the sins of fathers are not paid for by their sons, and masturbation is not viewed as a mortal sin.

It is also time for us to discard other atavisms, including pandering to religion and pretending that this out-dated, dogmatic endeavour is preordained to lead or advise us on any issue, ethical or otherwise. Dogma is not ethics.

\section{J. Hosken}

Centre for Ecology and Conservation, The University of Exeter in Cornwall, Tremough, Penryn, Cornwall TR10 9EZ, UK 